\title{
EQUiLIBRIUM
}

Quarterly Journal of Economics and Economic Policy

2014 VOLUME 9 ISSUE 4, December

p-ISSN 1689-765X, e-ISSN 2353-3293

www.economic-policy.pl

Brīvers, I. (2014). Alternative Views on Money in the First Half of the XX Century and Today. Equilibrium. Quarterly Journal of Economics and Economic Policy, 9(3), pp. 153-162, DOI: http://dx.doi.org/10.12775/EQUIL.2014.030

Ivars Brīvers*

BA School of Business and Finance, Latvia

\section{Alternative Views on Money in the First Half of the XX Century and Today ${ }^{* *}$}

JEL Classification: $B 22 ; B 31 ; E 42$

Keywords: money; fractional reserve; full-reserve banking; seigniorage; demurrage

\begin{abstract}
The paper deals with the discussion on the alternative ideas on money, created by Silvio Gesell, Frederic Soddy and Karl Ballod. Particularly, the ideas of full-reserve banking, privilege of seigniorage and the principle of demurrage are discussed in the context of possible implementation of these ideas in a future economy. Large part of the paper is library-based, considering and briefly explaining the previously mentioned ideas, and supplementing them with the opinions of the modern economists. The discussion of the possible evolutionary way to implement those ideas is based on the logical analysis and conclusions, derived from the discussions of the author with academicians and financiers. The results lead to the conclusion that these ideas, which may seem unrealistic according the existing paradigm of growth, may turn out to be useful to form the basis of a new monetary and financial system within the new economic paradigm. The paper is an insight into unorthodox proposals on money, which may be useful to specialists and students, investigating monetary and financial systems.
\end{abstract}

(C) Copyright Institute of Economic Research \& Polish Economic Society Branch in Toruń Date of submission: September 1, 2014; date of acceptance: November 18, 2014

* Contact: abrivere@td.lv, BA School of Business and Finance, Riga, Latvia

** The paper has been approbated at the $31^{\text {st }}$ Symposium on Money Banking and Finance in Lyon, France, on June, 2014. The Author expresses special thanks to Jerome Blanc (Universite Lyon 2) and Christian Rietsch (Universite d'Orleans) for useful comments on the paper. 


\section{Introduction}

The aim of this paper is to raise a discussion on alternative views on money in the $20^{\text {th }}$ and $21^{\text {st }}$ centuries. The current events clearly show that the conventional wisdoms on which the present economic paradigm is based should be revised, as the actual problems may have no solution in the framework of the existing paradigm. This concerns also the items of money, as among the sinister problems that may destroy the global society one may point out the problem of gigantic governmental debts, the problem of "non-patient capital", the problem of permanently increasing social inequality in a global scale, etc.

The current economic paradigm is outdated and leads to the abyss. The alternative views on money, which appeared from time to time in the history of economics, have to be lifted off the dusty shelf, and discussed from the point of view of modern economy. The ideas of Silvio Gesell, Frederic Soddy and Latvian economist Karl Ballod in the first part of the $20^{\text {th }}$ century are among such. The ideas of Gesell and Soddy were highly evaluated by John Maynard, who remarked, that they have come too early, and their time is in the future. The paper considers these ideas in comparison with the modern alternative views on money by Herman Daly, Andrew Simms, Ha-Joon Chang, and others.

The first chapter deals with the idea of fractional reserve banking, putting the discussion on the sustainability of that system. The emphasis is on the comparison of ideas of Frederic Soddy, compared to these of Herman Daly. The idea of fractional reserve banking has been put under impeachment by many modern economists at present, but no one can indicate the way to solve the problem.

Continuing the discussion of the previous chapter the second chapter deals with the unfair state of affairs, when the money supply comes not only from the public sector, but the private sector as well. There will be no such a problem with the full-reserve system. But with the fractional reserve system the problem perhaps could be at least partially solved, if the money creation rights could be given strictly to the public sector, i.e. state. This chapter contains the overview of ideas of Karl Ballod, and the discussion on the reality of such ideas in the modern society.

The third chapter considers the unfair situation, mentioned by Silvio Gesell that in the market there exists a contradiction between the actors from the supply-side, who mostly have to perform the act of exchange possibly sooner, and the actors from the demand-side, who are interested in the opposite, as money unlike the goods increases its value during time. Gesell was enthusiastic about the idea of demurrage - the idea of such money which decreases its value during time. The practical implementation of that 
idea in real life in a small Austrian town of Wörgl in 1932-1933, was indeed a success, but still this idea is put at the bottom of the box, and is rarely discussed in the economic textbooks and scientific discussions on money nowadays.

The paper does not deal with the monetary and financial systems of Islamic and Jewish world, which perhaps should be investigated when speaking about the alternative ways of money and finance.

\section{Methodology of the research}

The methodology of the conclusion making is based on qualitative historical analysis and empirical evaluation of the standpoints of the scientific discussion. The first part of the paper is mainly library-based. The ideas of world famous economists are taken from their own books in a printed form or the one that can be found on the Internet. The discussion and conclusions are based mainly on empirical observations of the author and debates with other academicians and financiers - Inesis Feiferis (Latvia), Kārlis Āboliņ̌s (Germany, Luxembourg), Vilnis Zakrevskis (Latvia).

\section{Fractional reserve banking versus full-reserve banking}

The fractional reserve system, when commercial banks lend the money which they indeed do not have, at first seems paradoxical and unbelievable to most people. However, learning about this system and becoming a part of it, they change their minds and then it seems impossible for them how economy can behave without the fractional reserve banking. Herman Daly pointed out: "On learning for the first time that private banks create money out of nothing and lend it at interest, many people find it hard to believe. Indeed, according to Joseph Schumpeter, as late as the 1920s, 99 out of 100 economists believed that banks could no more create money than cloakrooms could create coats. ... Nonetheless, most economists today accept this situation as normal. But the leading economists of the early twentieth century, Irving Fisher and Frank Knight, thought it was an abomination. And so did Frederick Soddy." (Daly \& Farley, 2011).

Frederic Soddy, the English radiochemist who won the Nobel Prize for Chemistry on 1921, is an author of some papers about the problems of the economy, among which there is his book "The Role of Money", published in 1934. Being a specialist in physics and chemistry, he tried to consider the economic problems rooted in physics, and suggested "a radical restructur- 
ing of global monetary relationships". Soddy's popular definition of money is: "Money now is the NOTHING you get for SOMETHING before you can get ANYTHING." (Soddy, 1934).

Soddy considered the existing irrational economic system as one of the fruits of science badly used. In his work "Wealth, Virtual Wealth and Debt", published in 1926, he pointed out that debt is a purely mathematical concept, in opposition to wealth- a magnitude with a physical dimension. The existing economic system puts them together, as if the increase of the debt from one side is the increase of wealth from the other side. But as debt and wealth are from different dimensions, this is false and the increase of debt from on side indeed is the increase of "virtual wealth" from the other side - such wealth which has no physical dimension. The Nobel Prize winner James Tobin later in 1965 called it "a fallacy of composition", explaining that the increase of the virtual wealth ("fiduciary issue", using the term of Tobin) indeed is an illusion of an increase in wealth. "The illusion can be maintained unimpaired as long as society does not actually try to convert all its paper wealth into goods" (Tobin, 1965).

The problem of the permanently increasing gap between the real wealth and virtual wealth has become dangerous for the existence of mankind in the beginning of the $21^{\text {st }}$ century. The gigantic governmental and private debts have reached unimaginable levels. We cannot evaluate the trillions and quadrillions of dollars from our everyday concepts; and only by calculating those debts per capita can one find that those debts are so enormously large that they can never be returned. The fractional reserve system, perhaps, is the lesser evil compared to the "financial innovations" in the speculative economy, which are often compared to the "weapons of mass destruction", as for instance it does Cambridge professor, Ha-Joon Chang in his book "23 Things They Don't Tell You about Capitalism", referring to the American financier Warren Buffet.

The contemporaries of Soddy - Frank Knight and Irving Fisher, which are considered even higher authorities of the economic thought, had the same opinion on the fractional reserve system: that it is not sustainable, it is based on the same principles as Ponzi scheme or any financial pyramid, and sooner or later the economy should return to the full-reserve system. In his efforts to "restructure global monetary relationships" Soddy suggested $100 \%$ reserve requirements for banks. Along with his two other suggestions: a policy of maintaining a constant price-index and internationally freely fluctuating exchange rates, it would be a way to restore honesty and order in the economic system.

Perhaps a large number of modern economists would agree with the idea of $100 \%$ reserve requirements. The banks, which represent the private sector, could no longer create money and would exist by providing their 
natural and basic services - the mediator of the dealings. The state then would be the sole issuer of the money, and the unfairness, described in the next chapter, will disappear by itself.

The recent English movie by Helena Norberg-Hodge and others "The Economics of Happiness" contains some interviews with English economist Andrew Simms, who points out that "One of the things we have to do, is to put finance back into its box, ..., separating speculative functions from the high stream, mainstream retail functions of the banking, so the money becomes our servant once more, rather than our master."

The problem is that if the change from fractional reserve banking to fullreserve banking were to be done in a revolutionary way, economies of most countries, perhaps, would collapse from such a shock. Is there any evolutionary way for that change?

Maybe the solution is the alternative local financial systems that would operate in parallel with the existing one. A creation of local small banks, according to the pattern of German "Volksbanken", which would operate with $100 \%$ reserve requirements, based on the local governments and supported by national government, obtaining trust and confidence among the population, would create a basis for gradual change of the existing economic system, which can hardly be considered as sustainable.

\section{The unfairness of creating money in the private sector}

As it was discussed in the previous chapter, the existing economic system with fractional reserve banking allows the economic actors from private sector to create money - a function that most of the people consider the sole priority of the state. "The one who creates money and is the first to spend it gets a real asset in exchange for a paper token. The difference between the monetary value and the negligible commodity value of the token, the profit to the issuer of money, is called seigniorage, in recognition of the lordly nature of this privilege. ... Historically it was the feudal lord, or the king, the sovereign, who issued money within his domain. One might expect that this privilege would have been passed on to the sovereign's legitimate heir, the democratic state. ... However, over $90 \%$ of our money supply today is not currency but demand deposits created by the private commercial banking system. ... Seigniorage from demand deposits goes to the private sector, initially to commercial banks." (Daly \& Farley, 2011).

That privilege of the commercial banks creates the situation that banking business is the most attractive for the economic resources - entrepreneurs, employees, and capital. A large amount of these resources go to the 
banking sector, and the "financial innovations" are those, who stop "the invisible hand", which otherwise would redistribute the resources, equalizing profitability in sectors of the economy. The problem of "non-patient capital" is widely discussed, for instance in the above mentioned book of Ha-Joon Chang, as well as in the publications of the mainstream economists (Bhagwati, 2008), and even politicians (Sarkozy, 2010). In addition, this kind of business is much more secure, as entrepreneurs in the banking system may justly expect that in case of threat of bankruptcy the government will try to rescue their business, in opposite to the businesses in the sectors of real economy.

Latvian economist Karl Ballod (Kārlis Balodis) mostly considered money as an external factor. His book "Ein Blick in den Zukunftsstaat", first published in 1898 contains a model for German economy, was based on quantitative calculations. This book deals with the monetary issues only as exogenous variables. In his book about the economy of Latvia, first published in 1928, Ballod also rarely considers the questions of money supply, still there is a chapter, where he discusses the question mentioned above about the acquisition of the seigniorage either in public of private sectors.

"70 years ago in Tsarist Russia state owned banks took the money on current accounts to $4 \%$, the real borrowers got money on long-term loan to $5 \%$, merchants bills of credit and mortgage loan products to $6 \%$. At that time of the absolute Tsar Nicholas I of Russia, the doctrine that banks may be owned only by private entrepreneurs - speculators had not yet been invented. This doctrine took place around 1860 with such success that the Russian government eliminated the state owned banks, and private bankers immediately pulled up the interest rates to $9-10 \%$. We now have 24 private banks in Latvia and hundreds of savings banks, which by large operate with the money of Bank of Latvia, i.e. with public money, and are trying to prove that they cannot even exist, if they don't get a 4-5\% profit margin. (At the time of Tsar Nicholas I the banks were living on a $1 \%$ profit margin, and even gave Russian state a notable profit). Not a single farmer can ask oneself: is it so that $90 \%$ of these financial intermediates are spare? Hundreds of those who get profit from the high profit margin convince farmers that a scientist who claims that the state itself would lend money without intermediaries is a fantast, and in reality it is not possible." (Balodis, 1931).

The ideas of Ballod to some degree correspond with those of Soddy. The unfairness of the fact that seigniorage can be acquired by some private entrepreneurs is common to both of them. The difference is that Ballod does not question the fractional reserve banking, but suggests that the seigniorage will go to the state as the only issuer of money, by giving the banks to the state ownership. Some ten years ago, when author of this paper 
very mildly touched upon the possibility of nationalization of the banks in some discussion, he was ridiculed. Some years later, in 2008, when the nationalization of banks became a reality, some of the participants of that discussion themselves seriously discussed on bank nationalization.

At present, I am rather skeptical about the idea of bank nationalization, although the possibility cannot be excluded in the future. It is true, at least in the post-soviet countries, that the common attitude to the collective owned property is much more careless than to the private property, and the management of public enterprises has a large risk of corruption and negligence.

\section{Silvio Gesell and the principle of demurrage}

A son of a Belgian mother and a German father, Silvio Gesell was born in 1862 in a small town of Sankt Vith, which at present is in the territory of Belgium, very close to the German border. Silvio Gesell had a large experience as a merchant, so his practice in this area was the basis of his theoretical ideas about money and economy as a whole, which were expressed in his book "Die natürliche Wirtschaftsordnung durch Freiland und Freigeld", published in 1916 in Switzerland.

The ideas of Silvio Gesell were very highly estimated by Irving Fisher, John Maynard Keynes, Lawrence Klein, and other world famous economists. Keynes considered the idea of Gesell that money will depreciate during time as a solution to the "liquidity trap", which perhaps could allow to create an economy without inflation. The experiment of Austrian community of Wörgl was an implementation of Gesellian ideas in real economy.

In his book, which was translated in English under a title "The Natural Economic Order", Gesell wrote: "Money is an instrument of exchange and nothing else. Its function is to facilitate the exchange of goods, to eliminate the difficulties of barter." (Gesell, 1958) At the existing system trading partners are not in equal positions, because money unlike the goods increases its value during time. That's why: "Supply is something detached from the will of owners of goods, so demand must become something detached from the will of the owners of money", and "As the owners of goods are always in a hurry for exchange, it is only just and fair that the owners of money, which is the medium of exchange, should also be in a hurry. Supply is under an immediate, inherent constraint; therefore demand must be placed under the same constraint." (Gesell, 1958).

Margrit Kennedy describes how the Gesellian ideas were implemented in a small Austrian town of Wörgl between 1932 and 1933. The town 
council issued 32000 "Work Certificates" or "Free Schillings", covered by the same amount of ordinary Austrian Schillings in the bank. The expenditures of public sector as well as salaries were paid with this money. It was accepted by the local residents.

"The fee on the use of the money was $1 \%$ per month or $12 \%$ per year. This fee had to be paid by the person who had the banknote at the end of the month, in the form of a stamp worth $1 \%$ of the note and glued to its back. Otherwise, the note was invalid.

This small fee caused everyone who got paid in Free Schillings to spend them before they used their ordinary money. People even paid their taxes in advance in order to avoid paying the small fee. Within one year, the 32,000 Free Schillings circulated 463 times, thus creating goods and services worth over 14,816,000 Schillings. The ordinary Schilling, by contrast, circulated only 21 times.

At a time when most countries in Europe had severe problems with a decreasing numbers of jobs, Wörgl reduced its unemployment rate by $25 \%$ within that one year. The fees collected by the town government which caused the money to change hands so quickly amounted to a total of $12 \%$ of 32,000 Free Schillings $=3,840$ Schillings. This was used for public purposes.

When over 300 communities in Austria began to be interested in adopting this model, the Austrian National Bank saw its own monopoly endangered. It intervened against the town council and prohibited the printing of its local money." (Kennedy, 1995).

The actual implementation of the Gesellian ideas in Wörgl can be evaluated as a success. Perhaps it is a question for another discussion why the experiment of Wörgl was stopped by the Austrian National bank. Nowadays, one can hardly imagine how to apply the principle of demurrage to such currencies as the dollar or the euro. Still it is possible with some local currencies of small communities, as it was in Wörgl. The idea of local currencies of different kinds, including such with the principle of demurrage, is growing more and more popular in Western Europe, and there are first attempts to put these ideas into action also in the Eastern Europe.

John Maynard Keynes in his essay "Economic Possibilities for Our Grandchildren" in 1930 wrote: "When the accumulation of wealth is no longer of high social importance, there will be great changes in the code of morals. We shall be able to rid ourselves of many of the pseudo-moral principles which have hag-ridden us for two hundred years, by which we have exalted some of the most distasteful of human qualities into the position of the highest virtues. ... I look forward, therefore, in days not so very remote, to the greatest change which has ever occurred in the material environment of life for human beings in the aggregate. But, of course, it will all 
happen gradually, not as a catastrophe." (Keynes, 1930). The frames, which are imposed on my minds by uncritical attitude towards conventional wisdoms, impede our efforts to find solutions to the global economic problems, which may seem to be unsolvable. The creative investigation of the alternative ideas of the great economists in the past may be the basis to create a new economic paradigm, which will serve for a better future.

\section{Conclusions}

The existing monetary and financial system may seem to be eternal. The problems that arise in the world, especially in the XXI century, may seem to be individual cases and to each of them individual solution can be found, without changing the whole system. The fractional reserve system is the core feature of our monetary and financial system since decades, and financiers as well as academicians are used to it, concerning that with all its shortcomings it will remain the best alternative forever. There are really serious arguments in favor of this system. As money is not neutral on production and activity, an exogenous supply of money that follows from the full-reserve system, will be mostly disadjusted with credit demand of the economy. Still these arguments are true in the existing paradigm of economy - growth paradigm. If we don't consider growth as the main goal of economy, and define crises as the slowdown of the growth; if we don't consider globalization as a permanent process, but allow that localization may prevail it in sooner of later future, the whole set of arguments in favor of fractional reserve system becomes less convincing. Obviously, it is a matter of research in which circumstances full-reserve system will be effective, and how to find an evolutionary way to it. Anyway, the problem of unfairness, discussed with the idea of seigniorage, could be less painful with the full-reserve system.

The third discussed idea - the principle of demurrage- is not necessarily linked with the first two and it can be investigated autonomously. Still, if the evolutionary way to the new monetary and financial paradigm discussed in this paper was based on financial institutions such as credit unions and small local banks, like German "Volksbanken" which would create local currencies, it could be useful to combine these ideas.

It is typical for each generation to consider that they have reached the optimal models of performance in any kind of activities, including monetary and financial systems. Still there is no final border to development, thus the alternative models, which at first may seem unrealistic, should be discussed and investigated, if there is even a minimal probability, that they may form the basis for the future systems. 


\section{References}

Ballod, K. (1898). Ein Blick in den Zukunftsstaat, Produktion und Konsum im Sozialstaat. Stuttgart: Dietz.

Balodis, K. (1931), Latvijas saimniecība pie spējìgas un pie nespējìgas valdības. Riga.

Bhagwati, J. (2008). We need to guard against destructive creation. Financial Times. October 16.

Chang, H. J. (2010), 23 Things They Don't Tell You about Capitalism. London: Penguine Books Ltd.

Daly, H.E. (1996). Beyond growth: the economics of sustainable development. Boston: Beacon Press.

Daly, H. E., Farley, J. (2011). Ecological economics: principles and applications. Washington, Covelo-London: Island Press.

Gesell, S. (1958). The Natural Economic Order. London: Peter Owen Ltd.

Kennedy, M. (1995). Interest and Inflation Free Money. Creating an Exchange Medium that Works for Everybody and Protects the Earth. Retrieved from http://kennedy-bibliothek.info/data/bibo/media/GeldbuchEnglisch.pdf (17.06.2014).

Keynes, J. M. (1930). Economic Possibilities for our Grandchildren In: D. Moggeridge (Ed.). The Collected Writings of John Maynard Keynes. Vol. IX. London: Macmillan, 1972.

Sarkozy, N. (2010). Speech in $40^{\text {th }}$ World Economic Forum, Davos, January 27, 2010. Retrieved from www.polity.org.za/article/fr-sarkozy-speech-by-thepresident-of-france-at-the-40th-world-economic-forum-davos-27012020-201001-27 (22.05.2010).

Soddy, F. (1934). The Role of Money. London: George Routledge and Sons Ltd.

Tobin, J. (1965). Money and Economic Growth. Econometrica, 33(4). 